\title{
Correction to: To detach or not to detach? The role of psychological detachment on the relationship between heavy work investment and well-being: A latent profile analysis
}

\author{
Maria Gaudiino $^{1}$ (D) $\cdot$ Giovanni Di Stefano $^{2}$ (D) \\ (C) Springer Science+Business Media, LLC, part of Springer Nature 2021
}

\section{Correction: Current Psychology (2021)}

https://doi.org/10.1007/s12144-021-01958-3

The original version of this article unfortunately contained a mistake. The article title should be "To detach or not to detach? The role of psychological detachment on the relationship between heavy work investment and well-being: A latent profile analysis".

The original article has been corrected.

Publisher's Note Springer Nature remains neutral with regard to jurisdictional claims in published maps and institutional affiliations.

The online version of the original article can be found at https://doi.org/ 10.1007/s12144-021-01958-3

\section{Giovanni Di Stefano} giovanni.distefano@unipa.it

1 Work and Organisation Studies, KU Leuven, Leuven, Belgium

2 Department of Psychology, Educational Science and Human Movement, University of Palermo, Palermo, Italy 